Bolm Inst. oceanogr., S Paulo, 33(1):69-78, 1985

\title{
NUMERICAL CONTRIBUTION OF PHYTOPLANKTONIC CELLS, HETEROTROPHIC PARTICLES AND BACTERIA TO SIZE FRACTIONATED POC IN THE CANANEIA ESTUARY $\left(25^{\circ} \mathrm{S} 48^{\circ} \mathrm{W}\right)$, BRAZIL
}

Hilda de Souza Lima MESQUITA \& Clovis de Araujo PERES

Instituto Oceanogräfico da Universidade de São Paulo Instituto de Matemática e Estatística da Universidade de São Paulo

\section{Synopsis}

Oxidable POC, at two stations in the Cananeia estuary, was found to be largely dependent upon the smallest size POC. The correlation factors between POC and the numerical abundance of cells, heterotrofic particles and bacteria, in each of the size categories studied, were generally low and non-significant for both stations, with a few exceptions. At St. I the number of heterotrophic particles seems to account for some of the POC variation over the year. At St. II, theoniy significant correlation found was between the number of the largest and intermediate size classes bacteria and the equivalent size classes POC. At this station the importance of the detritus component is suggested. The differences found between the stations, concerning the numerical contribution of cells, particles and bacteria to total POC, have been attributed to the differential hydrodynamic conditions acting upon material coming from land, due to diverse location of the stations. Sampling date and the collection of different water masses have also been considered as factors that may greatly affect the relationships studied.

Descriptors: Size distribution, Particulate organic carbon, Phytoplankton, Particle counters, Bacteria, Estuaries, Cananēia: SP, Brazil.

Descritores: Fracionamento, Carbono orgânico particulado, Fitoplâncton, Nümero de partículas, Bacteria, Estuärios, Cananēia: SP.

\section{Introduction}

Studies comprising differential filtration of suspended particulate organic matter into different sizes is a way to contribute for the understanding of the relative importance of parts of a planktonic community.

In the Cananéia estuary water sample fractionation have been carried out in previous studies, most of them concerned to phytoplankton and primary production (Teixeira, 1963; Teixeira, Tundisi \& Santoro Ycaza, 1967; Tundisi \& Texeira, 1968; Tundisi, 1969, 1971). The present report constitutes the first investigation undertaken in this environment, concerning to POC, heterotrophic particles and bacteria size fractionation, and is an integrant part of an investigation into the relationships between POC and some biotic environmental variables. Some of the results have already been reported in Mesquita (1983).

\section{Material and methods}

The present study was carried out at surface water samples taken from St. I Publ. n. 621 do Inst. oceanoar. da Usp. and St. II (Fig. 1), using a $9 \ell$ Van Dorn bottle, in the Cananéia estuary $\left(25^{\circ} \mathrm{S}\right.$ $\left.48^{\circ} \mathrm{W}\right)$, Brazil, over 1976. A preliminary filtration through a $100 \mu \mathrm{m}$ nylon netting was carried out on the samples to remove the larger particles and grazers. The $100 \mu \mathrm{m}$ sample was then size-fractionated, and the size fractions were gently concentrated by a reverse flow system based in Dodson \& Thomas (1964). The mesh size of the screens for the size fractionation were $50 \mu \mathrm{m}$ and $10 \mu \mathrm{m}$, and the finer filter was a $0,45 \mu \mathrm{m}$ Gelman Acropor membrane. Each filter was glued to a PVC cylinder $25 \mathrm{~cm}$ height and $12 \mathrm{~cm}$ wide. The maximum average value of the concentration factor was $3,4 \mathrm{X}$ for the smallest size categorie, 6,0 Xfor the 50-10 $\mu \mathrm{m}$ size class and 7,0 X for the largest size class. The average time required for concentrating the $10-0,45$ $\mu \mathrm{m}$ and the $50-10 \mu \mathrm{m}$ size categories was two and half an hour $(2 \mathrm{~h} 30 \mathrm{~m})$, and for the largest size class (100-50 $\mu \mathrm{m})$ was 5 minutes. The total time spent for the whole sample processing (screening and concentration) was at most 3 hours.

Plankton particle number (phyto- 


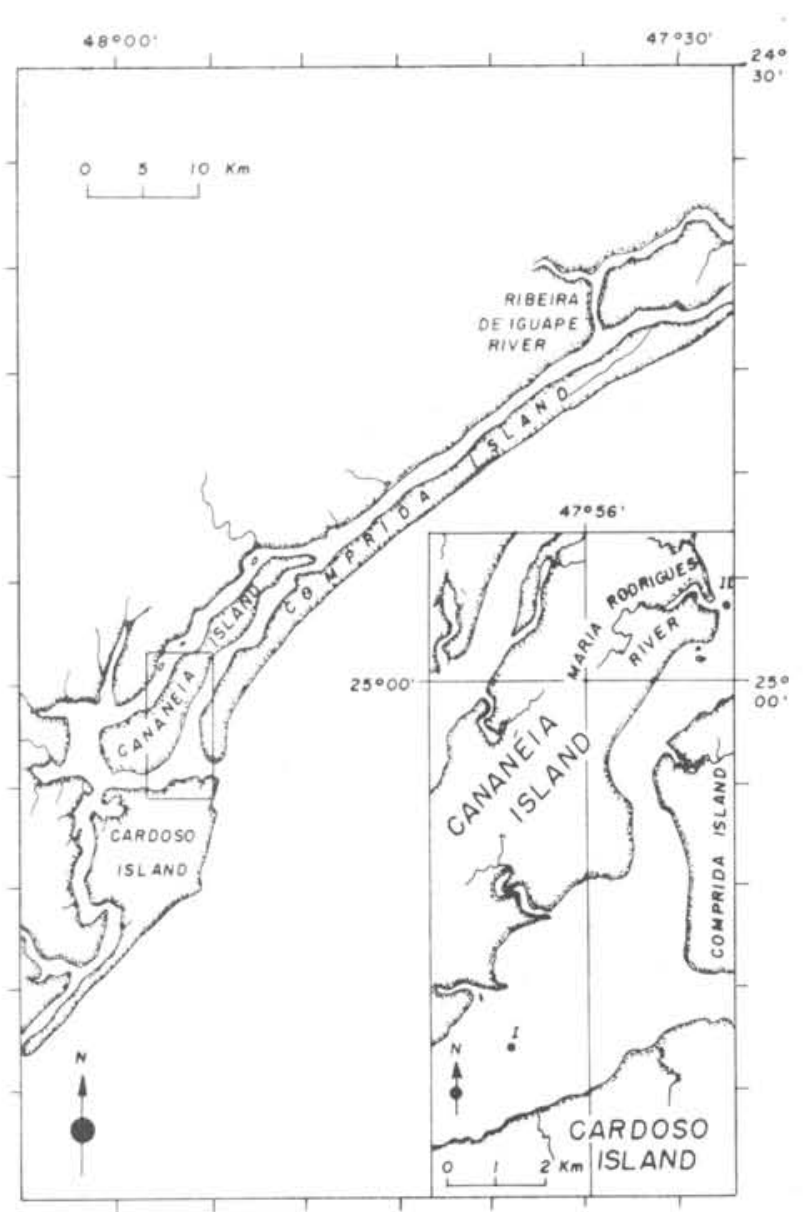

Fig. 1. Sampling stations at the Cananéia estuary: 1, Trapandé; II, Maria Rodrigues.

planktonic cells, heterotrophic particles and bacteria) and POC were monthly determined for 3 size classes: 100-50 $\mu \mathrm{m}$, 50-10 $\mu \mathrm{m}$ and 10-0,45 $\mu \mathrm{m}$ (Tabs 1-2). Cell counting was undertaken in a $20 \mu 1$ aliquot of the concentrate of each size categorie, using the fluorescence technique of Wood (1962). Cells showing bright red fluorescence under the fluorescent light (an HBO 200 mercury lamp) were considered as "phytoplanktonic cells" and their number was reported as "phytoplankton cell counting". After staining the particles with acridine orange dye (final concentration $1: 20,000)$, those particles displaying bright green color and distinct from bacterial cells by their size and morphology were designated "heterotrophic particles" and their number "heterotrophic particle counting". This group consists of a miscellaneous assemblage of particles, of difficult classification by the present methodology. The green fluorescence these particles show may be caused either by the uptake of the acridine orange dye or by their autofluorescence. Spores, fecal pellets, mineral material, cells or organisms without photosynthetic pigments may be included in this group.

Bacterial cells were considered as all the particles, distinct from the heterotrophic particles, that have shown bright green fluorescence after using the acridine orange dye.

A hundred $\mathrm{ml}(100 \mathrm{ml})$ aliquot of the concentrates of each size categorie, were strained through Whatman GF/C filters and, the carbon of the particulate matter retained was determined by oxidation using dichromic acid. Blanks were obtained by repeating the analysis on $\mathrm{GF} / \mathrm{C}$ filters previously wetted with sea water and rinsed with $25 \mathrm{ml}$ of $0,6 \mathrm{M} \mathrm{Na}_{2} \mathrm{SO}_{4}$ to remove halides. The method was calibrated against a standard glucose solution. The standard deviation of the analytical determination of the particulate organic carbon (POC) was $50 \mu \mathrm{g} \mathrm{C.} .1^{-1}$ or, approximately, $15 \%$ of the mean.

Temperature and salinity data are also presented at Tables 1 and 2 .

To have an indication of the correlation structure of the variable on Tables 1 and 2, the correlation coefficient for the following pairs of variable was calculated:

1) total POC and each of the three size classes POC;

2) phytoplankton cell number and the POC for each of the three size classes POC;

3) heterotrophic particle number and the POC for each of the three sizeclasses $\mathrm{POC}$ and,

4) bacterial cell number and the POC for each of the three size classes POC.

The coefficient of determination $\left(r^{2}\right)$ was calculated for each one of the situations described above, to show the percentage of variation of POC that can be attributed to the others variables. The results are shown in Table 3 .

For each one of the variables the percentage of each size classe with respect to the total was calculated (Tabs 1-2).

The lower limit of significance for the correlation factors obtained was chosen as 0,708 for the $1 \%$ level. 
Table 1. Some hydrological data, cell and particle densities, particulate organic carbon concentrations and size classes percentage of the total at Station I, over 1976. T = water temperature; $S=$ salinity; Phy= phytoplankton; $\mathrm{H}=$ heterotrophs; $\mathrm{B}=$ bacteria; $\mathrm{POC}=$ particulate organic carbon; $\%=$ size classes percentage of the total

\begin{tabular}{|c|c|c|c|c|c|c|c|c|c|c|c|}
\hline & $T$ & s & $\begin{array}{l}\text { size } \\
\text { class }\end{array}$ & Phy & & $H$ & & B & & $P O C$ & \\
\hline Date & $\left({ }^{\circ} \mathrm{C}\right)$ & $(\% / 00)$ & $(\mathrm{sim})$ & $\begin{array}{l}\text { cell no. } \\
\left(\times 10^{4}, 1^{-1}\right)\end{array}$ & $>$ & $\begin{array}{l}\text { part no. } \\
\left(\times 10^{4}, 1^{-1}\right)\end{array}$ & ? & $\begin{array}{l}\text { cell no. } \\
\left(\times 10^{6}, 1^{-4}\right)\end{array}$ & 3 & $\left(\mu g c, 1^{-1}\right)$ & 3 \\
\hline \multirow{3}{*}{$21 / 01 / 76$} & & & $100-50$ & 350.683 & 39 & 307.725 & 3 & 596.939 & 17 & 250 & 12 \\
\hline & 27.8 & 18.10 & $50-10$ & 214.637 & 24 & 2145.470 & 19 & 565.190 & 16 & 470 & 22 \\
\hline & & & $10-0.45$ & 333.531 & 37 & 8540.493 & 78 & 2396.991 & 67 & 1400 & 66 \\
\hline \multirow{3}{*}{$17 / 02 / 76$} & & & $100-50$ & 151.023 & 40 & 686.192 & 9 & 263.025 & 4 & 190 & 13 \\
\hline & 26.0 & 17.36 & $50-10$ & 116.074 & 31 & 1962.386 & 27 & 786.042 & 14 & 430 & 29 \\
\hline & & & $10-0.45$ & 111.703 & 29 & 4673.353 & 64 & 4745.050 & 82 & 870 & 58 \\
\hline \multirow{3}{*}{$24 / 03 / 76$} & & & $100-50$ & 45.876 & 11 & 676.969 & 36 & 87.111 & 14 & 470 & 52 \\
\hline & 25.8 & 15.13 & $50-10$ & 81.319 & 20 & $221: 642$ & 12 & 55.403 & 9 & 300 & 33 \\
\hline & & & $10-0.45$ & 280.965 & 69 & 984.544 & 52 & 496.864 & 78 & 140 & 15 \\
\hline \multirow{3}{*}{$22 / 04 / 76$} & & & $100-50$ & 37.531 & 22 & 26.141 & 14 & 12.984 & 6 & 290 & 38 \\
\hline & 25.0 & 20.16 & $50-10$ & 87.202 & 51 & 85.956 & 46 & 68.902 & 30 & 160 & 21 \\
\hline & & & $10-0.45$ & 45.462 & 27 & 74.999 & 40 & 145.582 & 64 & 320 & 42 \\
\hline \multirow{3}{*}{$18 / 05 / 76$} & & & $100-50$ & 6.716 & 11 & 137.346 & 17 & 78.202 & 28 & 140 & 17 \\
\hline & 22.2 & 21.58 & $50-10$ & 32.528 & 55 & 469.122 & 58 & 86.127 & 31 & 320 & 38 \\
\hline & & & $10-0.45$ & 19.785 & 34 & 201.605 & 25 & 117.388 & 42 & 380 & 45 \\
\hline \multirow{3}{*}{$22 / 06 / 78$} & & & $100-50$ & 8.987 & 14 & 60.514 & 13 & 8.011 & 8 & 150 & 19 \\
\hline & 19.5 & 21.00 & $50-10$ & 23.864 & 37 & 69.711 & 15 & 27.779 & 28 & 160 & 20 \\
\hline & & & $10-0.45$ & 31.344 & 49 & 331.484 & 72 & 64.051 & 64 & 470 & 60 \\
\hline \multirow{3}{*}{$20 / 07 / 76$} & & & $100-50$ & 3.701 & 5 & 189.386 & 47 & 11.421 & 15 & 70 & 11 \\
\hline & 18.5 & 17.46 & $50-10$ & 22.869 & 32 & 50.169 & 12 & 28.870 & 39 & 200 & 32 \\
\hline & & & $10-0.45$ & 44.532 & 63 & 161.125 & 40 & 34.231 & 46 & 360 & 57 \\
\hline \multirow{3}{*}{$24 / 08 / 76$} & & & $100-50$ & 34.108 & 27 & 57.498 & 12 & 33.717 & 11 & 150 & 14 \\
\hline & 18.5 & 24.30 & $50-10$ & 66.782 & 53 & 176.843 & 38 & 170.177 & 57 & 460 & 44 \\
\hline & & & $10-0.45$ & 26.036 & 20 & 234.846 & 50 & 95.932 & 32 & 430 & 41 \\
\hline \multirow{3}{*}{$14 / 09 / 76$} & & & $100-50$ & 4.654 & 6 & 21.261 & 10 & 11.928 & 5 & 100 & 16 \\
\hline & 19.5 & 23.44 & $50-10$ & 29.592 & 36 & 74.743 & 36 & 82.756 & 35 & 250 & 39 \\
\hline & & & $10-0.45$ & 47.142 & 58 & 110.625 & 53 & 139.899 & 60 & 290 & 45 \\
\hline \multirow{3}{*}{$20 / 10 / 76$} & & & $100-50$ & 6.620 & 16 & 16.670 & 12 & 12.408 & 7 & 0 & 0 \\
\hline & 22.0 & 26.60 & $50-10$ & 15.023 & 36 & 41.155 & 29 & 62.213 & 38 & 160 & 44 \\
\hline & & & $10-0.45$ & 20.476 & 49 & 84.900 & 59 & 90.262 & 55 & 200 & 56 \\
\hline \multirow{3}{*}{$23 / 11 / 76$} & & & $100-50$ & 84.677 & 34 & 45.783 & 10 & 31.917 & 10 & 150 & 7 \\
\hline & 25.8 & 26.46 & $50-10$ & 91.625 & 37 & 138.782 & 29 & 87.480 & 28 & 530 & 26 \\
\hline & & & $10-0.45$ & 72.985 & 29 & 291.348 & 61 & 90.319 & 61 & 1380 & 67 \\
\hline \multirow{3}{*}{$14 / 12 / 76$} & & & $100-50$ & 0.315 & 2 & 30.292 & 20 & 25.953 & 20 & 80 & 13 \\
\hline & 28.0 & 19.24 & $50-10$ & 11.664 & 76 & 50.506 & 34 & 75.048 & 57 & 210 & 34 \\
\hline & & & $10-0.45$ & 3.341 & 22 & 66.660 & 45 & 30.936 & 23 & 320 & 52 \\
\hline \multirow{3}{*}{$\begin{array}{l}\text { Annual } \\
\text { inean }\end{array}$} & & & $100-50$ & 61.241 & 29 & 188.007 & 10 & 97.801 & 10 & 170.00 & 17 \\
\hline & & & $50-10$ & 66.107 & 31 & 457.216 & 23 & 174.674 & 18 & 304.16 & 30 \\
\hline & 23.2 & 20.90 & $10-0.45$ & 86.525 & 40 & 1313.182 & 67 & 712.204 & 72 & 546.66 & 54 \\
\hline
\end{tabular}


Table 2. Some hydrological data, cell and particle densities, particulate organic carbon concentrations and size classes percentage of the total at Station 11 , over 1976. Further details as in legend to Table 1

\begin{tabular}{|c|c|c|c|c|c|c|c|c|c|c|c|}
\hline Date & $\begin{array}{c}\mathrm{T} \\
\left({ }^{\circ} \mathrm{C}\right)\end{array}$ & $\begin{array}{c}s \\
(\%)\end{array}$ & $\begin{array}{c}\text { Size } \\
\text { class } \\
\text { (um) }\end{array}$ & $\begin{array}{r}\text { Phy } \\
\text { cell no. } \\
\left(\times 10^{4}, 1^{-1}\right)\end{array}$ & 8 & $\begin{array}{l}{ }^{H} \\
\text { part no. } \\
\left(\times 10^{4}, 1^{-1}\right)\end{array}$ & 3 & $\begin{array}{l}\text { B } \\
\text { cell no. } \\
\left(\times 10^{6}, 1^{-1}\right)\end{array}$ & 2 & $\begin{array}{r}P O C \\
\left(\mu g C \cdot 1^{-1}\right)\end{array}$ & के \\
\hline \multirow{3}{*}{$21 / 01 / 76$} & & & $100-50$ & 350.683 & 39 & 307.725 & 3 & 596.939 & 17 & 250 & 12 \\
\hline & 27.8 & 18.10 & $50-10$ & 214.637 & 24 & 2145.470 & 19 & 565.190 & 16 & 470 & 22 \\
\hline & & & $10-0.45$ & 333.531 & 37 & 8540.493 & 78 & 2396.991 & 67 & 1400 & 66 \\
\hline \multirow{3}{*}{$17 / 02 / 76$} & & & $100-50$ & 151.023 & 40 & 686.192 & 9 & 263.025 & 4 & 190 & 13 \\
\hline & 26.0 & 17.36 & $50-10$ & 116.074 & 31 & 1962.386 & 27 & 786.042 & 14 & 430 & 29 \\
\hline & & & $10-0.45$ & 111.703 & 29 & 4673.353 & 64 & 4745.050 & 82 & 870 & 58 \\
\hline \multirow{3}{*}{$24 / 03 / 76$} & & & $100-50$ & 45.876 & 11 & 676.969 & 36 & 87.111 & 14 & 470 & 52 \\
\hline & 25.8 & 15.13 & $50-10$ & 81.319 & 20 & 221.642 & 12 & 55.403 & 9 & 300 & 33 \\
\hline & & & $10-0.45$ & 280.965 & 69 & 984.544 & 52 & 496.864 & 78 & 140 & 15 \\
\hline \multirow{3}{*}{$22 / 04 / 76$} & & & $100-50$ & 37.531 & 22 & 26.141 & 14 & 12.984 & 6 & 290 & 38 \\
\hline & 25.0 & 20.16 & $50-10$ & 87.202 & 51 & 85.956 & 46 & 68.902 & 30 & 160 & 21 \\
\hline & & & $10-0.45$ & 45.462 & 27 & 74.999 & 40 & 145.582 & 64 & 320 & 42 \\
\hline \multirow{3}{*}{$18 / 05 / 76$} & & & $100-50$ & 6.716 & 11 & 137.346 & 17 & 78.202 & 28 & 140 & 17 \\
\hline & 22.2 & 21.58 & $50-10$ & 32.528 & 55 & 469.122 & 58 & 86.127 & 31 & 320 & 38 \\
\hline & & & $10-0.45$ & 19.785 & 34 & 201.605 & 25 & 117.388 & 42 & 380 & 45 \\
\hline \multirow{3}{*}{$22 / 06 / 78$} & & & $100-50$ & 8.987 & 14 & 60.514 & 13 & 8.011 & 8 & 150 & 19 \\
\hline & 19.5 & 21.00 & $50-10$ & 23.864 & 37 & 69.711 & 15 & 27.779 & 28 & 160 & 20 \\
\hline & & & $10-0.45$ & 31.344 & 49 & 331.484 & 72 & 64.051 & 64 & 470 & 60 \\
\hline \multirow{3}{*}{$20 / 07 / 76$} & & & $100-50$ & 3.701 & 5 & 189.386 & 47 & 11.421 & 15 & 70 & 11 \\
\hline & 18.5 & 17.46 & $50-10$ & 22.869 & 32 & 50.169 & 12 & 28.870 & 39 & 200 & 32 \\
\hline & & & $10-0.45$ & 44.532 & 63 & 161.125 & 40 & 34.231 & 46 & 360 & 57 \\
\hline \multirow{3}{*}{$24 / 08 / 76$} & & & $100-50$ & 34.108 & 27 & 57.498 & 12 & 33.717 & 11 & 150 & 14 \\
\hline & 18.5 & 24.30 & $50-10$ & 66.782 & 53 & 176.843 & 38 & 170.177 & 57 & 460 & 44 \\
\hline & & & $10-0.45$ & 26.036 & 20 & 234.846 & 50 & 95.932 & 32 & 430 & 41 \\
\hline \multirow{3}{*}{$14 / 09 / 76$} & & & $100-50$ & 4.654 & 6 & 21.261 & 10 & 11.928 & 5 & 100 & 16 \\
\hline & 19.5 & 23.44 & $50-10$ & 29.592 & 36 & 74.743 & 36 & 82.756 & 35 & 250 & 39 \\
\hline & & & $10-0.45$ & 47.142 & 58 & 110.625 & 53 & 139.899 & 60 & 290 & 45 \\
\hline \multirow{3}{*}{$20 / 10 / 76$} & & & $100-50$ & 6.620 & 16 & 16.670 & 12 & 12.408 & 7 & 0 & 0 \\
\hline & 22.0 & 26.60 & $50-10$ & 15.023 & 36 & 41.155 & 29 & 62.213 & 38 & 160 & 44 \\
\hline & & & $10-0.45$ & 20.476 & 49 & 84.900 & 59 & 90.262 & 55 & 200 & 56 \\
\hline \multirow{3}{*}{$23 / 11 / 76$} & & & $100-50$ & 84.677 & 34 & 45.783 & 10 & 31.917 & 10 & 150 & 7 \\
\hline & 25.8 & 26.46 & $50-10$ & 91.625 & 37 & 138.782 & 29 & 87.480 & 28 & 530 & 26 \\
\hline & & & $10-0.45$ & 72.985 & 29 & 291.348 & 61 & 90.319 & 61 & 1380 & 67 \\
\hline \multirow{3}{*}{$14 / 12 / 76$} & & & $100-50$ & 0.315 & 2 & 30.292 & 20 & 25.953 & 20 & 80 & 13 \\
\hline & 28.0 & 19.24 & $50-10$ & 11.664 & 76 & 50.506 & 34 & 75.048 & 57 & 210 & 34 \\
\hline & & & $10-0.45$ & 3.341 & 22 & 66.660 & 45 & 30.936 & 23 & 320 & 52 \\
\hline \multirow{3}{*}{$\begin{array}{l}\text { Annual } \\
\text { mean }\end{array}$} & & & $100-50$ & 61.241 & 29 & 188.007 & 10 & 97.801 & 10 & 170.00 & 17 \\
\hline & & & $50-10$ & 66.107 & 31 & 457.216 & 23 & 174.674 & 18 & 304.16 & 30 \\
\hline & 23.2 & 20.90 & $10-0.45$ & 86.525 & 40 & 1313.182 & 67 & 712.204 & 72 & 546.66 & 54 \\
\hline
\end{tabular}




\section{Results}

Particulate organic carbon (POC) C. $1^{-1}$ )

$1 \mu 9$

At St. 1 except for March and August, the $10 \mu \mathrm{m}$ fraction contributed over the year at least $42 \%$ of the total organic carbon. The annual mean was $50 \%$.

At St. II the average annual percentage of the $10 \mu \mathrm{m}-0,45 \mu \mathrm{m}$ fraction was $43 \%$.

The carbon found in both the $50 \mu \mathrm{m}-10$ $\mu \mathrm{m}$ categorie and the $10 \mu \mathrm{m}-0,45 \mu \mathrm{m}$ size class comprised 84 and $79 \%$ of the total POC, at Sts I and II, respectively.

At both stations there was a highly significant and positive correlation, at $1 \%$ level, between total POC and the POC of the $10 \mu \mathrm{m}-0,45 \mu \mathrm{m}$ fraction (rSt.I = 0,$95 ; r_{S t}$.II $\left.=0,74\right)(\mathrm{Tab} \cdot 3)$. In general, it seems that the $C$ contribution of the smaller particles to total POC, dominates over the contribution of larger ones at both stations. The POC smallest size categorie seems to be relatively more important at St. I than at St. II, regarding its contribution to total POC.

\section{Standing-crop measurements:}

Phytoplankton cell counting (cells. $1^{-1}$ )

At St. I and on an annual basis the cell concentration in the $10 \mu \mathrm{m}-0,45 \mu \mathrm{m}$ size class comprised $40 \%$ of the total cell number. On the same annual basis the $50 \mu \mathrm{m}-10 \mu \mathrm{m}$ size group contribution to total cell number was $31 \%$. Therefore, at St. I and regarding their contribution to the total cell number the $50 \mu \mathrm{m}-10 \mu \mathrm{m}$ and $10 \mu \mathrm{m}-0,45 \mu \mathrm{m}$ size categories dominate over the $100 \mu \mathrm{m}-50 \mu \mathrm{m}$ size class.

At St. II, for part of the year the $50 \mathrm{jm}-10 \mu \mathrm{m}$ group dominate over the other size classes. This group, averaged annually $36 \%$ of the total. On an annual basis, the $<10 \mu \mathrm{m}>0,45 \mu \mathrm{m}$ size class comprised $26 \%$ of the total. Counts of particles larger than $50 \mu \mathrm{m}$ were relatively high-39\% of the total, annually (Tab. 2).

The phytoplankton cell counting in the size categorie between 50 and 0,45 $4 \mathrm{~m}$ was, on an annual basis, $71 \%$ of the total at St. 1 and $62 \%$ at St. I.

Therefore, it seems that small phytoplanktonic cells are, on an average, numerically important at both stations.

At St. I a significant positive correlation was found between POC and the phytoplankton counting in the $50 \mu \mathrm{m}-10 \mu \mathrm{m}$ size class, at $5 \%$ level. Phytoplankton cell counting in this size class accounted, over the year, for $43 \%$ $\left(r^{2}\right)$ of the POC variation in the same size categorie.

The phytoplankton cell counting in the $50 \mu \mathrm{m}-0,45 \mu \mathrm{m}$ fraction (the sum of the number of cells in the $<50 \mu \mathrm{m}>0,45$ $\mu \mathrm{m}$ and $\langle 10>0,45 \mu \mathrm{m}$ size classes), was significatively correlated with POC of the same size group at $5 \%$ level and, accounted for $34 \%\left(r^{2}\right)$ of its variation throughout the year.

At St. II no significant association was found between POC and phytoplanktonic cell number in any of the size groups considered.

Heterotrophic particle counting (particle no. $1^{-1}$ )

At St. I the relative contribution of the $10 \mu \mathrm{m}-0,45 \mu \mathrm{m}$ size group to total heterotrophic count ranged from 25 to $78 \%$ over the year, averaging annually $67 \%$ of the total.

The heterotrophic particle number in the size class between $10 \mu \mathrm{m}$ and $0,45 \mu \mathrm{m}$ has shown a highly significant and positive correlation with POC and accounted for $90 \%\left(r^{2}\right)$ of its variation in the same size group (Tab. 3).

Table 3. Correlation coefficient $(r)$ and coefficient of determination $\left(r^{2}\right)$ between $\mathrm{POC}$ and phytoplankton cell no. (Phy), heterotrophic particles number $(H)$, bacterial number (B) and total $P O C$ - for each size class, at St. I and II, over $1976 \mathrm{n}=10$

\begin{tabular}{|c|c|c|c|c|c|}
\hline Variables & $\begin{array}{c}\text { Size } \\
\text { classes } \\
\text { (um) }\end{array}$ & $\begin{array}{l}\text { Station } \\
r\end{array}$ & $\begin{array}{l}1 \\
r^{2}\end{array}$ & $\begin{array}{l}\text { Station } \\
\text { f }\end{array}$ & $\begin{array}{l}11 \\
r^{2}\end{array}$ \\
\hline \multirow{4}{*}{$\begin{array}{l}\text { Phy } \\
\text { (cell no, . } l^{-1} \text { ) }\end{array}$} & $100-50$ & 0.33 & 0.11 & 0.45 & 0,20 \\
\hline & $50-10$ & 0.66 & 0.43 & 0.44 & 0.19 \\
\hline & $10-0.45$ & 0.43 & 0.18 & 0.13 & 0.01 \\
\hline & $50-0.45$ & 0.58 & 0.34 & 0.05 & 0.00 \\
\hline \multirow{4}{*}{$\begin{array}{l}\text { H } \\
\left.\text { (particle no, }, l^{-1}\right)\end{array}$} & $100-50$ & 0.64 & 0.41 & 0.60 & 0.36 \\
\hline & $50-10$ & 0.55 & 0.30 & 0.29 & 0.08 \\
\hline & $10-0.45$ & 0.95 & 0.90 & 0.25 & 0.06 \\
\hline & $50-0.45$ & 0.67 & 0.45 & 0.53 & 0.28 \\
\hline \multirow{4}{*}{ (ce) } & $100-50$ & 0.30 & 0.09 & 0.76 & 0.58 \\
\hline & $50-10$ & 0.56 & 0.31 & 0.71 & 0.50 \\
\hline & $10-0.45$ & 0.47 & 0.22 & 0.42 & 0.18 \\
\hline & $50-0.45$ & 0.51 & 0.26 & 0.75 & 0.56 \\
\hline \multirow{4}{*}{$\begin{array}{l}\text { Total Poc } \\
\text { (uq } c \cdot \ell^{-1} \text { ) }\end{array}$} & $100-50$ & 0.31 & 0.09 & 0.71 & 0.50 \\
\hline & $50-10$ & 0.87 & 0.76 & 0.76 & 0.58 \\
\hline & $10-0,45$ & 0.95 & 0.90 & 0.74 & 0.55 \\
\hline & $50-0.45$ & 0.98 & 0.96 & 0.97 & 0.94 \\
\hline
\end{tabular}


Bolm Inst. oceanogr., S Paulo, 33(1), 1985

A significant and positive correlation at $5 \%$ o level between these variables was found in the $100 \mu \mathrm{m}-50 \mu \mathrm{m}$ size categorie (Tab. 3).

The number of heterotrophic particles in the size group between $50 \mu \mathrm{m}$ and 0,45 $\mu \mathrm{m}$ comprised on an annual basis $90 \%$ of the total and accounted for $45 \%$ of the $P O C$ variation over the year in the equivalent size categorie.

At St. II, throughout the year, the heterotrophic particle counting in the $10 \mu \mathrm{m}-0,45 \mu \mathrm{m}$ size class constituted on an annual basis $43 \%$ of the total. In the $50 \mu \mathrm{m}-0,45 \mu \mathrm{m}$ size group, the heterotrophic particles comprised annually $79 \%$ of the total (Tab. 2).

At this station the only significant correlation found between POC and heterotrophic particles was at 5\% level, in the 100 m-50 um categorie.

\section{Bacterial cell counting (cells. $1^{-1}$ )}

At St. I the bacterial number in the $10 \mu \mathrm{m}-0,45 \mu \mathrm{m}$ size fraction contributed during the year with $72 \%$ for the total bacterial number.

At St. II the $10 \mu \mathrm{m}-0,45 \mu \mathrm{m}$ size class constituted on an annual average $46 \%$ of the total bacteria counts. Throughout the year, the smallest size categorie generally dominated over the largest groups, except for January, August and September, when the $50 \mu \mathrm{m}-$ $10 \mu \mathrm{m}$ size group showed higher contribution to the total number of bacteria (Tab. 2).

Comparatively, at St. II was found a higher retention of bacteria in the larger size classes than at St. I. Awhile at St. I, on an average, $28 \%$ of the total number of bacteria, was found in the $100 \mu \mathrm{m}-10 \mu \mathrm{m}$ size group, at St. II this size categorie comprised $54 \%$ of the total bacterial number (Tabs 1,2 ).

At St. II correlation factors of bacterial number with POC, were positive and significant at $1 \%$ level only in the $50 \mu \mathrm{m}-10 \mu \mathrm{m}$ and $100 \mu \mathrm{m}-50 \mu \mathrm{m}$ size categories. Bacteria accounted for $50 \%$ and $58 \%$ of the POC variation over the year, respectively in the sizes classes between $50 \mu \mathrm{m}$ and $10 \mu \mathrm{m}$ and, $100 \mu \mathrm{m}$ and $50 \mu \mathrm{m}$ (Tab. 3).

Bacterial number in the $50 \mu \mathrm{m}-0,45 \mu \mathrm{m}$ size group comprised on an annual basis, $90 \%$ of the total at St. I and $80 \%$ at St. II (Tabs 1, 2).
At St. II, bacterial number was positively correlated (at $1 \%$ level) with POC, in the size class between $50 \mu \mathrm{m}$ and $0,45 \mu \mathrm{m}$, accounting for $56 \%$ of the POC variation in this size group.

\section{Discussion}

In the present work a few methodological difficulties should be mentioned. Although the aliquot for POC determination and the one for countings, were equally concentrated their volume were alike. Concentration of samples favors its representativity concerning the number, type and size of particles. Therefore, concentration minimizes the artefacts introduced by volume differences of the aliquots, though it does not cancel them. Accordingly, an over-representation of small particles in the smallest aliquot shall not be dismissed. On the other hand, counting is always a less precise way of assessing the standing-crop of particles than the analytical method used in the present work.

Another questionable point is concerned to the diverse retention characteristcs of the Whatman GF/C, used for filtering sub-samples for POC determination, and the Acropor Gelman membrane filters, used for sample size-fractionation, in relation to the smallest size particles. Sheldon (1972) has shown that the retention characteristics of the GF/C and the Millipore filters were very similar. The stated pore size of the Millipore and the Acropor Gelman membrane filters is 0,45 $\mu \mathrm{m}$. However, admitting a loss of material through the GF/C filter, and considering the precision of the analytical procedure used to be $50 \mu \mathrm{g}$ C. $1^{-1}$ it seems doubtful that this material would be detected by the wet oxidation technique used in the present work. On the other hand, for the microscope particle counting a $20 \mu 1$ aliquot was used awhile for the POC assessing $100 \mathrm{ml}$ aliquots of the same concentrate was utilized. In other words, for the POC measurement a $5000 \mathrm{X}$ greater aliquots were used.

With all these methodological limitations in mind and for the sake of data interpretation, the lower limit of significance for the correlation factor found, was chosen as 0,708 for the $1 \%$ level. 
It is apparent from the present results that the largest proportion of the total POC measured is concentrated in the size class between $0,45 \mu \mathrm{m}$ and $50 \mu \mathrm{m} .96$ and $94 \%$ of the total POC variation over the year, respectively at St. I and St. II, is attributed to POC variation in the smallest size groups.

Most of the phytoplanktonic cells, heterotrophic particles and bacteria were also found in the smallest size groups. Numerically, heterotrophic particles and bacteria, were more important than phytoplankters, at both stations.

The present results agree with many reports on the numerical dominance of the smallest size particles over the largest ones in marine environments (Teixeira, 1963; Hobson, 1967; Beers \& Stewart, 1969; Gordon, 1970a; Malone, 1971; Zeitzsche1, 1970; Lenz, 1972; Beers, Reid \& Stewart, 1975). Mullin (1965) has shown the preponderance of smallest size POC in surface waters of the Indian Ocean. The results of Gordon (1970b), on POC size classes in the North Atlantic Ocean were inconclusive.

The implications of such results on food chain studies have been discussed in the literature (Mullin, 1965; Jorgensen, 1966; Odum, 1968; Lenz, 1972; Poulet, 1973, 1974; Parsons \& Le Brasseur, 1970; Richman, Heinle \& Huff, 1977).

Generally, the correlations factor between POC concentration and the numerical abundance of the organic groups in each of the size classes studied, were low and non significant for both stations. The lack of correlation of POC with number of cells and particles in marine environments, have been pointed out by Gordon (1970b) and Zeitzschel (1970).

At St. I, in the smallest size group, a highly significant correlation, was found between total POC and the smallest size group POC, and of this with heterotrophic particle number suggesting the numerical importance of this group in its contribution to total POC.

Phytoplankton and bacteria does not appear to be numerically important at this station. At St. I, Mesquita (1983) has shown that phytoplankton carbon constitutes only a small fraction of the suspended particulate organic carbon and has suggested that the POC levels may have a relative high contribution of heterotrophs, most them depending indirectly upon the phytoplankton. At St. II, the quantities of phytoplanktonic organims and heterotrophic particles seem to be of minor significance as a factor affecting the levels of total POC. The numerical abundance of bacteria seems to be associated with POC in the largest size group and acçounts for some of its variation over the year. The significant correlation found between tota1 POC and POC of the largest size group, would suggest bacteria as an important factor affecting the POC levels in the water. Apparently, bacteria would also be numerically important in the $50 \mu \mathrm{m}-10 \mu \mathrm{m}$ size group, on account of its significant correlation with POC of the same size. However, for most of the year, bacteria in the smallest size group $(10 \mu \mathrm{m}-0,45 \mu \mathrm{m})$ dominates numerically over the other size classes studied. However, no significant correlation was found between bacterial densities and POC in the smallest size class. Relatively to St. I, this station shows greater predominance of detritus-attached bacteria over free-bacteria (Mesquita, 1978). The occurrence of large quantities of detritus attached-bacteria at St. II, may be an explanation for the relative higher retention of bacteria in the size classes between $10 \mu \mathrm{m}$ and $100 \mu \mathrm{m}$, and for its numerical dominance over the smallest size categories, a few times during the year.

The abundance of detritus-attached bacteria, the relative high retention of bacteria in the size classes greater than $10 \mu \mathrm{m}$ and, the lack of significant correlation between POC and bacterial number, in the smallest size class (where bacteria is most abundant), may suggest that it was not bacteria that would be carbon rich, but the detritus where it was found attached.

The POC measured has higher contribution of heterotrophic particles at St. I than at St. II. At St. II bacteria does not seem to be as important as the detritus that harbored them. In a previous study (Mesquita, 1983) the detritus quantities in the Cananéia estuary was shown to be greater at St. II than at St. I.

These differences found between stations, concerning the numerical importance of the organic categories 
Bolm Inst. oceanogr., S Paulo, 33(1), 1985

studied and their contribution to the POC pool, may be due to collection of diverse water masses as suggested by the salinity data, and considering that samples were taken at different days. However, it seems also likely that carbon, from sources that have not been considered in the present work, would interfere on the relationships between the variables.

In the Cananeia region, at the fringe of a tidal creek similar to St. II in the present work, the annual litter fall from the mangrove trees, was estimated to be $478 \mathrm{~g}$ dry weight $/ \mathrm{m}^{2}$ (Schaeffer-Novel1i et al., 1981), a figure approximately half of the majority of the litter fall values found for the most productive areas (Odum, McIvor \& Smith, 1982) studied up to now. It is known that in the Cananéia region, the material fallen does not accumulate on the forest floor, on account of the tidal flux. Therefore, a significant part of this material is exported to the estuary. Lugo et al. (1980) estimate that mangroves supply $32 \%$ of the organic carbon imput to Rookery Bay, in south Florida, a place where mangroves are importante but not the dominant source of carbon.

The differences found between the stations considered in the present report shall not be due to differential terrestrial imputs into the 2 stations, for both are within the typical mangrove region (Besnard 1950a,b; Gerlach, 1958). St. II is closer to land and shows smaller depth than St. I. Besides, St. $I$ is under larger influence of oceanic waters and St. II, of seepage ground water. Because of these, the circulation pattern at each of these stations may be different. Probably, St. II has better hydrodynamic conditions for retaining greater amounts of material coming from land than does St. I.

On the other hand, it should be mentioned the complex chemical effects that may occur in waters of varying and low salinities as those found at St. II. Colloidal particles are stabilised in fresh water by repulsion between their electric charges, but in sea water these charges are neutralised causing flocculation (Phillips, 1972). The characteristic yellow colour of the water coming from the mangrove catchment area suggest the significant occurrence of dissolved humic substances. Mostly of the terrestrially derived humic material precipitates out within the estuary or close inshore (Sieburth \& Jensen, 1968). Parsons (1975) stated that "the bulk of the particulate organic carbon in the immediate vicinity of some coastal areas or within the influence of large river is of terrestrial origin". Although the two stations considered in the present account are both within a coastal area, it is apparent the differential interference of allochthnous organic material in the relationships studied. At St. II the POC measured may be constituted by a significant fraction of alien organic naterial awhile at St. I it may represent better the general productivity of the water analysed.

\section{Acknowledgements}

The author greatly acknowledge the helpfull comments of Dr. Jean-Claude Romano, from Station Marine d'Endoume, Marseille.

This work was supported jointly by the "Fundaçäo de Amparo à Pesquisa do Estado de São Paulo" and "Instituto Oceanogrä́fico da Universidade de São Paulo".

\section{References}

BEERS, J. R. \& STEWART, G. L. 1969. Micro-zooplankton and its abundance relative to the larger zooplankton and other seston components. Mar. Biol., 4:182-189.

- REID, F. M. H. \& STEWART, G. L. 1975. Microplankton of the North Pacific Central gyre. Population structure and abundance, June 1973. Int. Revue ges. Hydrobiol., $60(5): 607-638$.

BESNARD, W. 1950a. Considerações gerais em torno da região lagunar de Cananéia-Iguape. I. Bolm Inst. paul. Oceanogr., 1(1):9-26.

1950b. Considerações gerais em torno da região lagunar de Cananéia-Iguape. II - Diversos aspectos atuais da regiăo lagunar. Bolm Inst. paul. Oceanogr., 1(2):3-28.

DODSON, A. N. \& THOMAS, W. H. 1964. Concentrating plankton in a gentle fashion. Limnol. Oceanogr., 9:445-456. 
GERLACH, S. A. 1958. Die mangroveregion Tropicher Küsten als lebensraum. Z . Morphol. Ökol. Tiere, 46:636-730.

GORDON, D. C. 1970a. A microscopic study of organic particles in the North Atlantic Ocean. Deep Sea Res., 17:175-185.

1970b. Some studies on the distribution and composition of POC in the North Atlantic Ocean. Deep Sea Res., 17:233-243.

HOBSON, L. A. 1967. The seasonal and vertical distribution of suspended particulate matter in an area of the Northeast Pacific Ocean. Limnol. Oceanogr., 12:642-649.

JORGENSEN, C. B. 1966. Biology of suspension feeding. Oxford, Pergamon Press, 357p.

LENZ, J. 1972. The size distribution of particles in marine detritus. Memorie Ist. ital. Idrobiol., 29 ( $\operatorname{supp} 1): 17-35$.

LUGO, A. E.; TWILLEY, R. R. \& PATTERSONZUCCA, C. 1980. The role of black mangrove forests in the productivity of coastal ecosystems in south Florida. Report to E.P.A. Corvallis. Corvallis, Oregon, Environmental Research Laboratory, 281p.

MALONE, T. C. 1971. The relative importance of nannoplankton and netplankton as primary producers in the California Current system. Fishery Bul1. NOAA, 69(4):799-820.

MESQUITA, H. de S. L. 1978. Taxa de consumo de oxigênio pelo plâncton, nas águas de superfície da região de Cananéia $\left(25^{\circ} \mathrm{S} 48^{\circ} \mathrm{W}\right)$, Estado de São Paulo. Tese de doutorado. Universidade de São Paulo, Instituto de Biociências. 244 p.

1983. Suspended particulate organic carbon and phytoplankton in the Cananéia Estuary $\left(25^{\circ} \mathrm{S} 48^{\circ} \mathrm{S}\right)$, Brazil. Océanogr. trop., $18(1): 55-68$.

MULLIN, M. M. 1965. Size fractionation of particulate organic carbon in surface waters of the western Indian Ocean. Limnol. Oceanogr., 10:459-462.

ODUM, W. E. 1968. The ecological significance of fine particle selection by the striped mullet Mugil cephalus. Limnol. Oceanogr., 13(1): 92-98.

\section{J. 1982. The ecology of the mangroves of South Florida: a community profile. U.S. Fish and Wildlife Service. Office of Biological Services, Washington, D.C. FWS/OBS-81/24. 144p.}

PARSONS, T. R. 1975. Particulate organic carbon in the sea. In: Riley, J. P. \& Skirrow, G., eds - Chemical oceanography. 2nd ed. London, Academic Press, vol. 2 p.365-381.

\& LE BRASSEUR, R. J. 1979. The availability of food to different trophic levels in the marine food chain. In: Steele, J. H., ed. - Marine food chains. Edinburg, Oliver \& Boyd, p.325-343.

PHILlips, J. 1972. Chemical processes in estuaries. In: Barnes, R. S. K. \& Green, J., eds - The estuarine environment. London, Applied Science Publishers, p.33-50.

POULET, S. A. 1973. Grazing of Pseudocalanus minutus on naturally occurring particulate matter. Limnol. Oceanogr., 18:564-573.

\section{Seasonal grazing} of Pseudocalanus minutus on particles. Mar. Bio1., 25:109-123.

RICHMAN, S.; HEINLE, D. R. \& HUFF, R. 1977. Grazing by adult estuarine copepods of the Chesapeake Bay. Mar. Biol., 42(1):69-84.

SCHAEFFER-NOVELLI, Y.; ADAIME, R.R.; CAMARGO, T. M. \& CINTRON, G. 1981. Os manguezais de Cananéia $\left(25^{\circ} \mathrm{S}\right.$, Brasi1) I - Estimativa da produção de serapilheira na região do "rio" Nóbrega. VIII Simpósio latinoamericano sobre Oceanografia Biológica, 15-19 Noviembre 1981, Acapulco, Guerrero, Mexico. 
SHELDON, R. W. 1972. Size separation of marine seston by membrane and glass-fiber filters. Limnol. Oceanogr., 17(3):494-418.

SIEBURTH, J. McN. \& JENSEN, A. 1968. Studies on algal substances in the sea. I. Gelbstoff (humic material) in terrestrial and marine waters. J. exp. mar. Biol. Ecol., 2:174-189.

TEIXEIRA, C. 1963. Relative rates of photosynthesis and standing stock of the net phytoplankton and nanoplankton. Bolm Inst. oceanogr., S Paulo, 13(2): 53-60.

; Tundisi, J. \& SANTORO-YCAZA, J. 1967. Plankton studies in a mangrove environment. IV. Size fractionation of the phytoplankton. Bolm Inst. oceanogr., S Paulo, 16(1): 39-42.

TUNDISI, J. 1969. Produção primāria, "standing-stock" e fracionamento do fitoplâncton na região lagunar de $\mathrm{Ca}$ nanéia. Tese de doutorado. Universidade de São Paulo. Faculdade Filosofia, Ciências e Letras. 130p.
TUNDISI, J. 1971. Size distribution of the phytoplankton and its ecological significance in tropical waters. In: Costlow Jr., J. D., ed. - Fertility of the sea. New York, Gordon \& Breach, vol. 2 , p. 603-612.

$$
\text { \& TEIXEIRA, C. } 1968 .
$$

Plankton studies in a mangrove environment. VII. Size fractionation of the phytoplankton: some studies on methods. Bolm Inst. oceanogr., S Paulo, 17(1):89-94.

WOOD, E. J. F. 1962. A method for phytoplankton study. Limnol. Oceanogr., $7(1): 32-35$.

ZEITZSCHEL, B. 1970. The quantity, composition and distribution of suspended particulate matter in the Gulf of California. Mar. Biol., 7: 305-318.
(Received 01-0ct-1984; accepted 11-Apr-1985) 